\title{
UMA ESPÉCIE E UMA SUBESPÉCIE NOVAS DE TRIGONINI DO OESTE DA AMAZÔNIA (HYMENOPTERA, APIDAE, MELIPONINAE) ${ }^{1}$
}

\author{
Jesus Santiago Moure ${ }^{2}$
}

\begin{abstract}
A NEW SPE(IES ANI) A NEW SUBSPECIES OF TRIGONINIFROM THE WESTERN Amazonia (Hyminoptlika, APII)Al Mel..poninae). Plebeia alvarengai. sp.n. is one of the most distinctive member of the smaller Pleheia (3.2 mm long); its richness of yellow coloration (legs completely yellow) helps to distinguish this species from the related ones and from specimens from Puerto Maldonado, Peru, with the distal third of hind tibiae and hasitarsi largely darkened, and here recognized as a distinet subspecies, namely Pleheia alvarengai peruvicola. subsp.n.

KEY WORDS. Apidae, Meliponinae. Plebeia. Amazonian Region
\end{abstract}

Estou arrumando pouco a pouco a coleção de Meliponinae do Departamento de Zoologia da Universidade Federal do Paraná, para dar a conhecer algumas espécies que havia deixado in litteris desde o início da década de 60 quando me envolvi mais intensamente no estudo da reforma da Universidade Brasileira. Naqueles anos foi grande a pressão resultante da observação atenta do funcionamento das Universidades e outros Institutos como grandes ambientes de pesquisa nos Estados Unidos e na Europa e surgiu um impulso irresistível para fazer algo pelo aprimoramento das nossas Universidades. Foi o grande envolvimento político-administrativo para juntar harmonicamente Departamentos, e principalmente para criar a Pós-graduação na sua estrutura atual. Embora nem todos os ideais debatidos nessa época fossem alcançados, contudo chegou-se a um modelo mais próximo e um grande avanço foi conseguido nessa área, ainda que com grande perda da minha parte, pois havia deixado numerosos exemplares com nomina in litteris em coleções americanas e européias, que pouco a pouco vêm sendo aproveitados, com ou sem reconhecimento daquele fato inicial por outros pesquisadores.

A espécie em pauta, e abaixo descrita, provém do Oeste Amazônico Brasileiro, entrando um pouco no Peru e chegando até o Sul de Mato Grosso. A pressão para uma solução do seu status foi feita por solicitação de alguns pesquisadores da Universidade Federal de Viçosa, Minas Gerais, que trabalharam por algum tempo na Amazônia e que agora necessitam dos nomes para dar a conhecer o resultado de seu trabalho.

As medidas apresentadas entre parênteses, estão indicadas em centésimos de milímetro, caso não haja indicação em contrário.

1) Contribuição número 797 do Departamento de Zoologia. Universidade Federal do Paraná.

2) Departamento de Zoologia, Universidade Federal do Paraná, Caixa Postal 19020, 81531-970

Curitiba. Paraná. Brasil. Bolsista do CNPq. 
Está entre as espécies menores de Plebeia, adornada de numerosos desenhos amarelos, sendo que as pernas da forma típica são inteiramente desta cor.

Operária de tamanho pequeno. Comprimento total aproximado 3,2-3,4mm, da asa anterior $3,2 \mathrm{~mm}$; largura da cabeça $1,5 \mathrm{~mm}$ e do segundo tergo $1,35 \mathrm{~mm}$.

Colorido de fundo castanho-claro, com numerosos desenhos de um amarelo-vivo. Amarelos: o clípeo, marginado estreitamente de castanho; as estrias paroculares, alargadas ao nível dos alvéolos, atenuadas para baixo e mais acentuadamente para cima, terminando aos $5 / 7$ da órbita; a supraclipeal com uma prolongação progressivamente diluída e estreitada para a fronte; a metade inferior das genas; o labro; as mandíbulas, com o bordo apical pardo e a extremidade basal preta; o escapo, com uma estria preta no terço distal superior; o flagelômero basal um pouco amarelo. No tórax: a faixa pronotal ligada aos lobos pronotais, igualmente amarelos; as estrias laterais do mesoscuto, ligeiramente encurtadas na frente; as axilas e o contorno posterior do escutelo (este um pouco pardo no disco); o metanoto; uma mancha alongada vaga, atrás, nos mesepisternos; todas as pernas por inteiro, com fina linha preta acompanhando o bordo posterior das tíbias do terceiro par. As tégulas translúcidas com mancha anterior; as asas hialinas, fortemente irisadas, estigma e venação amarelentos, ligeiramente para o pardo. Propódeo pardo-ocráceo-claro; tergos pardo-ocráceos com largas faixas amarelas marginais, interrompidas nos dois primeiros (a do primeiro mais largamente), as demais inteiras.

A pilosidade pouco desenvolvida, normal, esbranquiçada; um pouco mais plumosa nas genas, nos lados do tórax e principalmente nos flancos do propódeo. As cerdinhas eretas no vértice até 180 micra, no escapo claramente mais curtas que o diâmetro do mesmo (40-50 micra); no escutelo e no último tergo até 200 micra.

A pontuação pilígera muito fina; na fronte e no mesoscuto muito esparsa (os pontos separados por dois a quatro diâmetros de ponto), os intervalos lisos e brilhantes. A área basal do propódeo inteiramente lisa e brilhante, glabra.

Cabeça mais larga que longa, comprimento dos olhos 2,35 vezes sua largura (106:45); as genas, de perfil, mais estreitas (30) e a área malar linear (3); órbitas mais convergentes embaixo, a interorbital máxima praticamente igualando o comprimento do olho (85:105:75); clípeo chato, seu comprimento um pouco mais que a metade da largura, porém mais curto que a metade da sua distância ao ocelo médio (36:66:82); distância interalveolar quase igual ao diâmetro do alvéolo, porém apenas a metade da alveolorbital; distância interocelar o duplo do diâmetro do ocelo médio e cerca de uma vez e meia a distância ocelorbital (28:18:d 14). As mandíbulas delicadamente bidentadas no quarto interno do bordo apical. Escapo cinco vezes mais longo que seu diâmetro, cerca de 7/9 da distância alveolocelar lateral (52:10:67) e mais curto que a metade do comprimento do pedicelo e flagelo juntos; os flagelômeros claramente mais curtos que seus diâmetros e o segundo um pouco mais curto que o basal (10:8:10:d 12). Escutelo ligeiramente parabo- 
lóide, pouco mais longo que a metade da sua largura (32:60). O hasitarso médio 2,8 vezes mais longo que largo; nas pernas posteriores o fêmur cerca de $2 / 3$ do comprimento da tíhia, esta quase 2,8 vezes sua largura apical (90:134:48); o basitarso quase duas vezes mais longo que largo (57:30), com o bordo posterior convexo atenuado mais acentuadamente para a base e o bordo apical sinuado junto à articulação com o tarsômero basal, o canto posterior em ângulo um pouco inferior a $u$ m reto, de ápice arredondado; as cerdas corbiculares mais longas cerca de 220-230 micra .

Holótipo e três parátipos. Brasil, Pará: Jacareacanga, X.1959, M. Alvarenga leg., a quem é dedicada a espécie pela imensa contribuição pessoal ao conhecimento da nossa insectofauna. Todos depositados na Coleção Entomológica Pe. Jesus Santiago Moure, Departamento de Zoologia, Universidade Federal do Paraná.

\section{Plebeia alvarengai peruvicola, ssp.n.}

Operária. Numerosos exemplares de Pleheia alvarengai podem ser imediatamente separados da forma típica pelo colorido pardo escuro mais acentuado em todo o corpo, dando maior realce às manchas amarelas e principalmente pelo terço distal escuro das tíhias posteriores e basitarsos do mesmo par; o abdômen com faixas marginais estreitas, inteiras, de cor pardo-castanha, relativamente estreitas e a base predominantemente amarela.

Holótipo e 12 parátipos operárias. PERU: Madre de Dios, Puerto Maldonado, 31.IX.1962, Luis Peña G. leg. Todos depositados na Coleção Entomológica Pe. Jesus Santiago Moure, Departamento de Zoologia, Universidade Federal do Paraná.

Em alguns exemplares, talvez mais jovens, o escurecimento do terço distal das tíhias posteriores um pouco desbotado.

O nome é alusivo ao país de ocorrência da subespécie.

Recebido em 12.1.1994; aceito em 29.1II.1994. 